\title{
The Founding of The Lurline H. Coltharp Collection of Onomastics
}

\author{
Lurline H. Coltharp
}

The University of Texas at El Paso

\begin{abstract}
This description of the founding and development of the Coltharp Collection was written at the specific request of Professor E. Wallace McMullen.
\end{abstract}

In the late 1970s I taught a class called simply "The Study of Names." Among many fine students in that class was Yvonne Greear, who was Assistant Librarian in the University Library at that time. She became fascinated with names, and even after that class was over, she and I frequently conferred about books, especially books about names and naming. As part of her job, she ordered books for the Library. I ordered for my personal collection and use and we made sure that we ordered different books so that we would enlarge the range available to us in El Paso. For several years, other matters commanded my attention. However, in 1983 I started what I thought would take a lifetime to accomplish: namely, establishing an endowment for an onomastic collection at the University of Texas at El Paso Library. Through the generous gifts of friends and family, the fund needed to establish the collection reached the goal in a relatively short time. By 1991 the Collection was fully funded.

At the beginning I knew very little - actually nothing - about collecting, but through the staff at the Library and friends, I learned. Dick Woods told me, "specialize." With this in mind we started with Mexico. We reviewed our resources and found that we already had a number of treasures. We owned a set of all the maps and gazetteers for Mexico that had been published by the Instituto Nacional de

Names 43.2 (June 1995):158-161

ISSN:0027-7738

- 1995 by The American Name Society 
Estadistica, Geografia e Informatica. These items are especially valuable now because the agency building where they were produced was destroyed in the big earthquake in Mexico City, and the agency has not been re-established.

The University Library which houses the collection offered to print a special bookplate if I would design it. I asked Bob Kolliker, a Swiss artist whose work appealed to me and he agreed to do the job. The distinctive owl bookplate (which appears at the bottom of this report) was then placed in each volume. The next project suggested by the staff was the production of a brochure describing the collection and its goals.

In the meantime the Library was moved to a new building and underwent several changes in staff. Happily, each time such events took place the next administration gave our project its unstinting support.

The next request was for publicity for the special collection. This came from Mary Keckley and Carol Kelley, members of the Library staff.

Our ambitious project was announced in such publications as Hispania, American Speech, PADS (Publications of the American Dialect Society), the Information Bulletin of the Western Association of Map Libraries, The Name Gleaner (Canadian Society for the Study of Names), Onomastica Canadiana, The Transboundary Resources Report, The TLA Cast (of the Texas Library Association), and The Medallion (of the Texas Historical Commission), and in the publications of the American Name Society, including The Ehrensperger Report and Names. Furthermore, information about the collection was widely disseminated through the El Paso newspapers and the University of Texas at El Paso publications.

When Roberta Arney suggested publishing a bibliography of the collection to supplement the computer listing, the Library offered to publish one periodically. The first one to be compiled was based on a list already in existence to which certain additions were made. Then it was time for the surgeon's knife. It was necessary for me to go through all of the listed books unfamiliar to me, to be sure that each one was about names and not just lexical terms sometimes called "names." Accordingly, we removed those that were inappropriate. 
The bibliography itself has been issued several times: in 1989 (with 25 pages), in 1990, in 1991, and again in 1993 (when the entries had expanded to fill 73 pages).

Throughout this time the incoming gifts of books and articles have been nothing short of astounding. Len Ashley gave us our first large gift - fifty volumes, consisting of the gazetteers of each of the fifty states. Since the Library is also a federal depository, we have been able to augment the collection with government publications provided by Don Orth and Roger Payne, and through orders placed by our map librarian, David Larkin. My own special interest in placenames has led to an enlargement of that subject area of the collection. However, we do try to see that all the various onomastic areas are represented.

Since the names of all the donors (68 individuals and organizations as of August, 1993) are listed in the most recent bibliography, they won't be included here, but one particular gift has led to a new emphasis in procedure. Don Clark of Santa Cruz, California, willed his personal onomastics library to the collection. This is a wonderful way to donate because it ensures the giver the use of the books for a lifetime and provides a good home for them where they can assist future scholars.

Ed Lawson has proven to be a valuable gadfly. Each time I am ready to relax and take life easy, he writes to suggest further steps. Because of his suggestions and help, we now have received the books and papers of the American Name Society, and we receive books and journals from the current editor of Names. Outstanding is the only word for the help given us by Helen Kerfoot from Canada. We are also receiving gifts from scholars and organizations in a number of foreign countries, from South Africa to Germany. Offprints and similar materials are stored in vertical files and are being alphabetized by author.

One very happy event was the combined meeting here at the University of Texas at El Paso, in September of 1993, of the Western States Geographic Names Conference, the U.S. Board on Geographic Names and the Place Name Survey of the United States. Many participants came bearing gifts, and many learned of the rich resources we can now offer. 
Among the pleasures of operating the collection are having scholars pay us visits, and receiving students who make use of our resources. Also thrilling is sharing our onomastic interests worldwide. In January of 1993 we had a request from Singapore and faxed an article there. In February a call from New York for a specific book was answered through inter-library loan.

All onomastic scholars are urged to spread the word that the collection is available to all through the Internet, interlibrary loan, or a letter addressed to "Roberta Arney, The Collection of Onomastics, The Library, The University of Texas, El Paso, TX 79968."

Originally I had envisioned setting up the endowment of the collection and then going off in other directions. But that is not how it works. Each new plateau in procedure that we reach necessarily increases our labor, even though it may indeed be a labor of love. What I hadn't realized previously was that the collection would take a lifetime of work - happy work, rewarding work - but still work.

Founding a scholarly collection is not for the faint of heart.

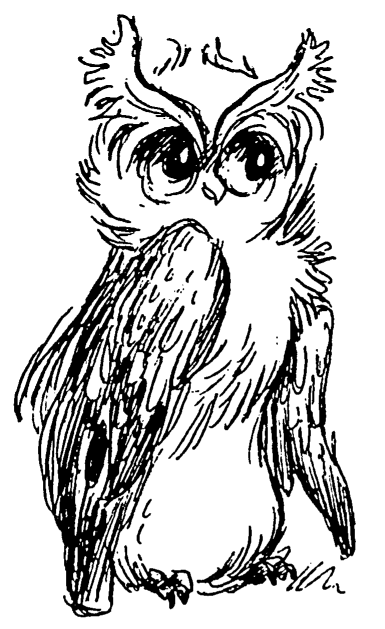

\section{The \\ Lurline H. Coltharp \\ COLLECTION \\ of Onomastics}

The University of Texas at El Paso Library 